\title{
Farmers' pesticide usage practices in the malaria endemic region of North-Western Tanzania: implications to the control of malaria vectors
}

\author{
Anitha Philbert ${ }^{1 *}$, Sylvester Leonard Lyantagaye ${ }^{2}$ and Gamba Nkwengulila ${ }^{1}$
}

\begin{abstract}
Background: Pesticides remain the mainstay for the control of agricultural pests and disease vectors. However, their indiscriminate use in agriculture has led to development of resistance to both crop pests and disease vectors. This threatens to undermine the success gained through the implementation of chemical based vector control programs. We investigated the practices of farmers with regard to pesticide usage in the vegetable growing areas and their impact on susceptibility status of An. gambiae s.l.

Methods: A stratified multistage sampling technique using the administrative structure of the Tanzanian districts as sampling frame was used. Wards, villages and then participants with farms where pesticides are applied were purposively recruited at different stages of the process, 100 participants were enrolled in the study. The same villages were used for mosquito larvae sampling from the farms and the surveys were complimented by the entomological study. Larvae were reared in the insectary and the emerging 2-3 days old female adults of Anopheles gambiae s.l were subjected to susceptibility test.

Results: Forty eight pesticides of different formulations were used for control of crop and Livestock pests. Pyrethroids were the mostly used class of pesticides (50\%) while organophosphates and carbamates were of secondary importance. Over $80 \%$ of all farmers applied pesticides in mixed form. Susceptibility test results confirmed high phenotypic resistance among An. gambiae populations against DDT and the pyrethroids (Permethrin-0.75\%, Cyfluthrin-0.15\%, Deltametrin-0.05\% and Lambdacyhalothrin-0.05\%) with mortality rates 54, 61, 76 and $71 \%$, respectively. Molecular analysis showed An. arabiensis as a dominant species (86\%) while An. gambiae s.s constituted only $6 \%$. The kdr genes were not detected in all of the specimens that survived insecticide exposures.

Conclusion: The study found out that there is a common use of pyrethroids in farms, Livestocks as well as in public health. The study also reports high phenotypic resistance among An. gambiae s.l against most of the pyrethroids tested. The preponderance of pyrethroids in agriculture is of public health concern because this is the class of insecticides widely used in vector control programs and this calls for combined integrated pest and vector management (IPVM).
\end{abstract}

Keywords: Pesticides, Insecticides, Malaria vectors, Farmers, Resistance, Magu

\footnotetext{
* Correspondence: annybyabato@yahoo.com

${ }^{1}$ Department of Zoology and Wildlife Conservation, University of Dar es

Salaam, Dar es Salaam, Tanzania

Full list of author information is available at the end of the article
}

(c) The Author(s). 2019 Open Access This article is distributed under the terms of the Creative Commons Attribution 4.0 International License (http://creativecommons.org/licenses/by/4.0/), which permits unrestricted use, distribution, and reproduction in any medium, provided you give appropriate credit to the original author(s) and the source, provide a link to the Creative Commons license, and indicate if changes were made. The Creative Commons Public Domain Dedication waiver (http://creativecommons.org/publicdomain/zero/1.0/) applies to the data made available in this article, unless otherwise stated. 


\section{Background}

Malaria is still a major public health challenge globally and especially in Sub-Saharan Africa (SSA) region. According to the 2017 World Malaria report, 91 countries reported 216 million cases of malaria in 2016, this is an increase of 5 million cases compared to the previous records of 2015, the increase in malaria cases has resulted to 445 , 000 mortalities [1]. Currently, the control of malaria depends on two strategies, which are vector control using insecticides and case treatment using anti-malaria drugs. Nevertheless, vector control is considered as an essential part for reducing malaria transmission [2]. The control of malaria vectors relies on two insecticide based operational scale interventions, indoor residual spraying (IRS) and deployment of long-lasting insecticide-treated nets (LLINs) $[2,3]$. The scaling up of insecticide based interventions (IRS and LLINs) has shown positive impacts by reducing both malaria related morbidities and mortalities in various areas such as Equatorial Guinea, Malaysia, Angola and Zanzibar [4-7]. Notwithstanding the achievements gained in the control of malaria through the insecticide based interventions (IRS and LLINs), the challenge is how to sustain the gains. Major challenges are costs, inappropriate use of specific intervention, lack of community acceptance $[8,9]$ and rising of insecticide resistance in the primary malaria vectors: Anopheles gambiae and Anopheles funestus species complexes [3].

Magu district, the present study area is one of the districts around the Lake Victoria Zone, the area that has highest malaria prevalence [10]. In attempt to reduce malaria burden in the country, the Government through the National Malaria Control Program (NMCP) has in the past 15 years increased LLINs through universal distribution and increased IRS coverage. In 2006, IRS operations were initiated in Kagera region and by 2011 the operations had extended to most of districts around the Lake Zone area including Magu district. IRS operations started with using a pyrethroid (lambdacyhalothrin), and the insecticides have from time to time been replaced following the emergence of resistance in the targeted vectors. Bendiocarb which is a carbamate was introduced in 2009, and an organophosphate pirimiphosmethyl was recently introduced in in 2014 $[10,11]$.

Insecticide based interventions are considered the most effective measure to prevent malaria transmission [12]. However, there are a limited number of insecticides that are recommended for use in LLINs and IRS. Currently, most vector control programs are largely dependent on synthetic pyrethroids, which are the only WHO-recommended insecticides for treatment of bed nets [13] and widely used in IRS programs. The same class of insecticide is also used in agriculture and veterinary for control of both crop and livestock pests. Agricultural areas form important breeding habitats of disease vectors [14-16] therefore, such proximity of the vectors with the insecticide residues from both agriculture and public health use poses inherent risk of increased selection pressure to malaria vectors. Globally and in Tanzania, considerable work has been done on human's health impacts resulting from pesticide misuse and mishandling [17-20], but the effect of these misuse and mishandling to other untargeted species such as disease vectors is under explored. A study by Ngowi et al. [19], reported that about a third of vegetable growers in Northern Tanzania applied pesticides in mixed form. The spill offs from these pesticide cocktails can easily find their way to the mosquito breeding habitats that are located within and around the farms thereby causing selection pressure. These malpractices of pesticide users therefore, warrant further attention to investigate their potential impacts to the environment and other untargeted species such as disease vectors. The present study was therefore designed to assess the practice of farmers with regard to pesticide usage in relation to resistance status of An. gambiae s.l in surrounding breeding sites in agricultural settings of Magu district in Tanzania. The indiscriminate use of agricultural pesticides against crop pests constitutes, therefore, a public health issue in most malarious countries.

\section{Methods}

\section{Study sites}

The study was conducted in agricultural areas of Magu district $\left(02^{\circ} 35^{\prime} \mathrm{S}-033^{\circ} 26^{\prime} \mathrm{E}\right)$ in Mwanza region, Tanzania. Magu district is bordered to the north by Lake Victoria where most of the vegetables are grown along the Lake Shore. The study was conducted between January through September 2014, and took into consideration the cropping and pesticide application seasons. The farms selected were located in the following vilages: Sola, Ijitu, Kiloleli and Ilumya. The selection of villages was based on the history of past and current use of pesticides (in agriculture, livestock and public health), malaria endemicity and availability of mosquito breeding habitats. The target population was the farmers of vegetables and fruits (tomatoes, cabbages, cucumber and water melons), livestock keepers, dealers of pesticides and other farm inputs in Agroverts, also the agricultural extension officers found within the area.

\section{Study design}

A stratified multistage sampling technique using the administrative structure of the Tanzanian districts as sampling frame was used. Wards, villages and then participants with farms where pesticides are applied were purposively recruited at different stages of the process. The same villages were used for mosquito larvae sampling. Study participants were randomly selected from a list of names of heads of households obtained from the respective village executive officers. A total of 100 participants were enrolled in the study, these were obtained 
with assistance from the village executive officers and the agricultural extension officers.

\section{Data collection}

Collection of data on the pesticide usage practices was mainly done by two methods: (i) administration of questionnaires (Additional file 1) and (ii) personal observation of the agricultural practices (Pesticide handling, spraying techniques, waste disposal etc) in the farms, shops and households that were visited. To generate adequate information on the practice of farmers, surveys were organized in the study sites of Sola, Ijitu, Kiloleli and Ilumya villages. Structured and semi-structured questionnaires were administered to 100 respondents, the population study composed of farmers, livestock keepers, retailers and dealers of pesticides in agroverts located within the study site. The tool was formulated in English but was translated and administered in Kiswahili (language common to all Tanzanians) to ensure maximum understanding of the questions by the participants but care was taken to retain the original meaning. The questionnaires focused on the history of vegetable farms, the size of farms, educational level of farm owner, type of pesticides used, farmer's source of information on pesticide use, pesticide sources and availability, farming techniques and the pesticide treatment strategies (spraying methods, mixture and quantities), the frequencies, longevity and time of pesticide application in the farms. Qualitative data were recorded by direct observations and in-depth interview to key informants (extension officers, farmers and pesticide dealers). Direct observations were made in agroverts, farms and households to examine various pesticide management practices such as pesticide mixing (ratios), spraying techniques, storage, packing and disposal. During observations, farmers were not informed beforehand in order to avoid modifications of their behavior with regard to pesticide handling and to reduce the response bias. All respondents gave a verbal consent to participate in the study and were allowed to withdraw from the study if the need arises.

\section{Mosquito larvae sampling}

Mosquito larvae and pupae were collected from the vegetable farms in Magu district and brought to the insectarium at the National Institute for Medical Research (NIMR), Mwanza center for rearing to adults. The collection was conducted between January to September 2014 covering the three main seasons which coincide with pesticide applications: rainy $(262.1 \mathrm{~mm}$-January to March), short rains (18.1 mm-May to June) and dry season (104.4 mm-August to September). The collected larvae were sorted and only Anophelines were reared to adults. The larvae were fed on tetramine fish food $(0.02$ g dissolved in $500 \mu \mathrm{l}$ of distilled water for $(100-120$ larvae $)$ in a plastic white tray $(15 \times 30 \mathrm{~cm})$ and reared at laboratory conditions of $25-27^{\circ} \mathrm{C}$ and $67-79 \%$ relative humidity (ICIPE,1997 unpublished). The emerging female adults were morphologically identified using the published keys by Gillies and De Meillon [21] also Gillies and Coetzee [22]. Only the mosquitoes in the An. gambiae complex were obtained in sufficient number for susceptibility testing. The sibling species of An. gambiae s.l were further confirmed during molecular analyses by PCR after susceptibility testing.

\section{Susceptibility test}

The emerging adult females aged 2-5 days old were subjected to susceptibility tests using insecticideimpregnated papers, as described by the WHO testing protocol [23]. The insecticides tested were the five pyrethroids compounds: permethrin $(0.75 \%)$, deltamethrin (0.05\%), lambdacyhalothrin (0.05\%), etofenprox $(0.5 \%)$ and cyfluthrin $(0.15 \%)$, and the organochlorine DDT (4\%). For each insecticide, 15-20 mosquitoes in each bottle were exposed to insecticide and each experiment had 4 replicates and 1 control. DDT was tested to detect the presence of cross-resistance with the pyrethroids in Anopheles gambiae s.l. Mosquitoes were exposed to insecticide-treated papers for $60 \mathrm{~min}$ and the knock down times were recorded at the following intervals: (10, $15,20,30,45$ and $60 \mathrm{~min}$ ). Mortalities were recorded 24 $\mathrm{h}$ post insecticide exposure and according to the 2013 WHO protocol, when the mortality rate is $>98 \%$, the population is considered fully susceptible; a mortality rate between 97 to $98 \%$ means resistance is suspected, and when the mortality rate is $<97 \%$, it means the population is resistant and resistance genes have to be confirmed [23]. Surviving specimens were killed by being frozen at $-20^{\circ} \mathrm{C}$, both the dead and surviving specimens were individually kept in a $1.5 \mathrm{ml}$ eppendorf tube lined with silica gel beads for molecular studies.

\section{Sibling species identification and $K d r$ genotyping}

Mosquito species in the Anopheles gambiae s.l were identified by optimizing the conditions and following the procedure of Scott et al. [24], the reaction mixture contained primers based on the species composition available in East Africa. The universal primer was 3'GTGTGC CCCTT CCTC GAT GT 5'; the reverse primers were: 5'AAGTGTCCTTCTCCATCCTA3'-(An.arabiesnsis), 5'CTGGTTTGGTCGGCACGTTT3’ (An. gambiae s.s), 5'TGACCAACCCACTCCCTTGA3' (An. merus), and 5'CAGACCAA G ATGGTTAGTAT 3’ (An. quadrianulatus). These are the common species available in the area [25]. The identification of Anopheles gambiae complex sibling species is based on species-specific single nucleotide polymorphisms (SNPs) in the intergenic spacer region (IGS) [24]. The knock down $(k d r)$ 
resistance gene both western and eastern variants were determined by normal PCR following the published procedure of Martinez-Torres et al. [26] and Ranson et al. [27] respectively.

\section{Data analysis}

Data from the questionnaires were entered and doublechecked for quality control in the excel sheet. All responses from the structured and semi-structured questions were then summarized for all participants and analyzed using descriptive statistics including frequency distribution, percentages and means. The susceptibility status of malaria vectors (An. gambiae s.l) was evaluated based on the 2013 WHO guidelines [23]. Testing the interactions of resistance status among An. gambiae populations for the 5 pyrethroids tested was done using Multiple Analysis of Variance (MANOVA). The software used is GraphPad version 6.01. The time taken for 50 and $95 \%$ of all mosquitoes to knock down (knockdown times) was estimated by the Log Probit Model analysis using the time-mortality curves. The software used is Origin Pro 8.5, version 84E, 2010, Origin Lab Corporation. In addition, the resistant ratios were calculated using the KDT50 between the wild mosquitoes and the susceptible laboratory strain (Kisumu).

\section{Results}

\section{Demographic data}

The demographics for the 100 participants are summarized as follows: the average age was 37 years, $75 \%$ of all participants were males and $25 \%$ were females. For the case of farmers, generally, each farmer had worked on a farm at least for the past 10 years. The majority of participants $(80 \%)$ had completed standard seven education, a few $(17 \%)$ completed secondary education and very few $(3 \%)$ had post-secondary education and attended colleges.

\section{Pesticides used for the control of pests in the surveyed area}

A total of 48 pesticides of different formulations were commonly used in the control of crops and livestock pests in the surveyed area (Table 1). This figure was obtained from the summation of the list given by farmers and extension officers that were matched with the list given by pesticide retailers, as well as direct observations in the field by inspecting and direct reading from the pesticide labels, the duplicates were removed. However, the reported total number could be low compared to the actual number since many farmers could not recall all the names of pesticides they usually apply. Pyrethroids were the mostly used class of pesticides (50\%), followed by Organophosphates (15\%), Carbamates (11\%), Organochlorides (9\%), and $15 \%$ of the pesticides are from other chemical groups. The classification of the pesticides by chemical group, trade name, active ingredients and status of registration is given in Table 1.

\section{Classification of pesticides based on the pests they control}

The classification of the pesticides based on the type of pests they control revealed that, Insecticides are the most used group (57\%), followed by Fungicides (15\%), Acaricides (9\%), and Hebicides (6\%). However, 13\% of the pesticides were used multipurposely, for example, a pesticide could be used as an insecticide and acaricide at the same time, example (Duduthrin super- active ingredient: Lambdacyhalothrin). Similarly, some Fungicides (Movil- active ingredient: Hexaconozole) and Herbicides (Agriothrine- active ingredient: Agritone) were also used as insecticides. In Fig. 1, the classification of these pesticides by type of pests they control is presented.

\section{Pesticide cocktails}

During the surveys, tomato farmers were seen mixing various pesticides in the same tanks / container for spraying their crops. Many times, there were no specific mixing instructions or procedures followed. The commonly mixed pesticides were the Fungicides and Insecticides also Fungicide and herbicides as summarized in Table 2:

\section{Pesticide usage practices}

The frequency distribution of the responses from farmers on various pesticide usage practices are summarized in Table 3: It was learned from some farmers during the study that they sought information about pesticides because they could not understand the labels, which are normally always written in English, although some were labeled in both languages (Swahili and English).

\section{Susceptibility status}

A total of 2205 mosquito larvae of Anopheles gambiae s.l were collected from which 1500 adults females were obtained. For each season, 450 adults were tested, 75 mosquito adults (60 exposed and 15 control) for each insecticide for the three seasons. The adults were exposed to the Pyrethroids (Permethrin 0.75\%, Deltamethrin $0.05 \%$, Lambdacyhalothrin $0.05 \%$, Etofenprox $0.5 \%$, Cyfluthrin $0.15 \%$ ) and DDT $4 \%$. The susceptibility test results are presented in Table 4. During the season of long rains, the population of An. gambiae s.l was fully susceptible to Lambdacyhalothrin (100\% mortality) whereas high resistance level were recorded against Cyfluthrin (61\% mortality rate) during the same season. High resistance levels were recorded during the dry season against Permethrin, Lambdacyhalothrin and Deltamethrin; mortality rates of 55,71 and $76 \%$ respectively. The mortality rate of An. gambiae s.l was consistently 
Table 1 Types of pesticides commonly applied in vegetable farms and on livestocks as reported by farmers in Magu district, Mwanza region

\begin{tabular}{|c|c|c|c|}
\hline $\begin{array}{l}\text { Pesticide chemical } \\
\text { group (\% in use) }\end{array}$ & Trade name & Active ingredient & $\begin{array}{l}\text { Status of } \\
\text { registration }\end{array}$ \\
\hline & Albadip & 10\% Alphacypermethrin & $R$ \\
\hline & Agrothrin & Lambdacyhalothrin & R \\
\hline & Bamethrin & Deltamethrin & R \\
\hline & Baygon & Imiprothrin + Cyfluthrin & $\mathrm{R}$ \\
\hline & Decis $25 \mathrm{EC}$ & Deltamethrin & R \\
\hline & Degor & Cypermethrin & NR \\
\hline \multirow[t]{16}{*}{ Pyrethroids (50\%) } & Cyclone 505EC & Cypermethrin 10\%+Chlorpyrifos & $\mathrm{R}$ \\
\hline & Insectido 5EC & Lambdacyhalothrin & R \\
\hline & Karate 5EC & $50 \mathrm{~g} / \mathrm{L}$ of Lambdacyhalothrin & R \\
\hline & Kungfu & $50 \mathrm{~g} / \mathrm{L}$ of Lambdacyhalothrin & $\mathrm{R}$ \\
\hline & Cybadip & Cypermethrin & $\mathrm{R}$ \\
\hline & Duduthrin super & Lambdacyhalothrin & R \\
\hline & Fenom & Lambdacyhalothrin + Profenofos. & R \\
\hline & Fenkil 20EC & Fenvalerate $20 \mathrm{~g} / \mathrm{L}$ & R \\
\hline & Helarat & Lambdacyahalothrin & $\mathrm{R}$ \\
\hline & Paranex 100 EC & Alphacypermethrin $100 \mathrm{~g} / \mathrm{L}$ & NR \\
\hline & Rapid attack & Cypermethrin \& Imidacloprid & R \\
\hline & Shamba powder & Deltamethrin \& Fenitrothion & $\mathrm{R}$ \\
\hline & Subachlo & Cypermethrin & $\mathrm{R}$ \\
\hline & Suba Deltamethrin & Deltamethrin & NR \\
\hline & Ultracya 5EC & Lambdacyhalothrin 5\% & R \\
\hline & Farmerzeb & Mancozerb 80\%WP & $P R$ \\
\hline \multirow[t]{3}{*}{ Carbamates (11\%) } & Linkmil 72 WP & Metalaxyl 80 kg + Mancozeb & R \\
\hline & Bamic/Ascomec & Abamectin & $\mathrm{R}$ \\
\hline & Milthane super & Mancozeb & R \\
\hline \multirow[t]{7}{*}{ Organophosphates (15\%) } & Insecron 720EC & Prefonofos & NR \\
\hline & Mocron 720EC & Prefonofos & R \\
\hline & Prefonos & Endosulfan & NR \\
\hline & Selecron 720EC & Profenofos & R \\
\hline & $\begin{array}{l}\text { Supercron/Mupacron } \\
\text { Prefonofos 500EC }\end{array}$ & Prefonofos 500EC & R \\
\hline & Profecron/Banofos & Prefonofos $720 \mathrm{E} C$ & R \\
\hline & Sume & Dimethoate & R \\
\hline \multirow[t]{5}{*}{ Organochlorides (9\%) } & Muparaxone & Paraquat $270 \mathrm{~g} / \mathrm{l}$ & $\mathrm{RR}$ \\
\hline & Thiodan & Endosulfan & NR \\
\hline & Linkonl & Chlorothelonil 50\% & \\
\hline & Thionex & Endosulfan & $P R$ \\
\hline & Abanil/Bamic & $\begin{array}{l}\text { Abamectin } 18 \mathrm{~g} / \mathrm{L} \\
\text { (Avermectin) }\end{array}$ & R \\
\hline \multirow[t]{6}{*}{ Others } & Agriothrine & Agritone & NR \\
\hline & Ascomine 2-4-D & $\begin{array}{l}\text { 2-4D Amine salt } \\
\text { (Aryloxyalkanoic acid) }\end{array}$ & R \\
\hline & Bamitraz & Amitraz (Amidine) & R \\
\hline & Kumulus DF & $80 \%$ Sulphur & R \\
\hline & Movil & Hexaconozole & R \\
\hline & Tixfix/Tiktik & $\begin{array}{l}\text { Amitraz 12.5\% EC } \\
\text { (Formamidine) }\end{array}$ & R \\
\hline
\end{tabular}


Table 1 Types of pesticides commonly applied in vegetable farms and on livestocks as reported by farmers in Magu district, Mwanza region (Continued)

\begin{tabular}{lll}
\hline $\begin{array}{l}\text { Pesticide chemical } \\
\text { group (\% in use) }\end{array}$ & Trade name & $\begin{array}{l}\text { Active ingredient } \\
\text { registration }\end{array}$ \\
\hline & Glyphon (Glyphosate) & $\begin{array}{l}\text { Isopropylamine salt } \\
\text { (Phosphanoglycine) }\end{array}$
\end{tabular}

$R$ Registered for use, NR Not registered, $R R$ Registered for Restricted use, $P R$ Provisional Registration (Registration status as per Tanzania Pesticides Gazette, 2011)

less than $5 \%$ in all the control groups and therefore the correction factor for the control mortality was not performed. In addition, the reference strain (Kisumu) was fully susceptible ( $100 \%$ mortality) $24 \mathrm{~h}$ post exposure to all the insecticides tested. The susceptibility test results are presented in Table 4.

Moreover, data analysis indicates that mortality rates of Anopheles gambiae s.l were significantly influenced by seasons; $\quad p$-value $=0.007, \quad \mathrm{X}$-squared $=24.421, \quad \mathrm{df}=10$ (Pearson's Chi-squared test). Nevertheless, there was no significant difference of mortality rate between individual insecticides and season, as demonstrated by Multiple Analysis of Variance-MANOVA, $(P=0.225, \mathrm{~F}(1.6,17))$.

\section{Sibling species identification and $K d r$ genotyping}

A total of 130 mosquitoes survived insecticide exposure (Table 4). A total of 1000 mosquitoes were randomly selected from the samples that died after insecticide exposure and 130 specimens that survived the exposure were further subjected to An. gambiae s.l sibling species identification by PCR. Out of 1130 specimens, $86 \%$ were Anopheles arabiensis and only $8 \%$ were Anopheles gambiae s.s and the remaining $6 \%$ of the sampled failed to amplify and couldn't be identified.

\section{Knockdown times}

The time taken to knock down 50 and 95\% (KdT50 and KdT95) respectively are presented in Table 5. The knockdown times were compared against mortality rates of An. gambiae s.l. During the short rain season, the knock down times against Lambdacyhalothrin were significantly longer for An. gambiae s.l compared to Kisumu; $P<0.05$.The corresponding values are $28 \mathrm{~min}, 68$ min and 114 min for Kisumu, KdT50 and KdT95 for An. gambie s.l respectively and the corresponding resistance ratio was 2.4 implying $k d r$ based mechanism of resistance. During the dry season, long knock down times were recorded against Deltamethrin and DDT as compared to Kisumu; $\mathrm{P}<0.05$ and the corresponding resistance ratios were 2.2 and 1.9 respectively.

\section{Knock-down resistance mutations ( $k d r)$}

A total of 130 mosquitoes that survived insecticide exposure were further subjected for $k d r$ genotyping (both eastern and western variants). $K d r$ mutation alleles were not detected in all the samples that were tested and therefore sequencing was not performed. This implies that mechanisms other than $k d r$ were responsible for the phenotypic resistance recorded among the population of An. gambiae s.l in this study site.

\section{Discussion}

The present study has observed the indiscriminate and intensified pesticide use of 48 different formulations in the study area. The use of a high number of different formulations in Tanzania had been reported before. Ngowi et al. [19] reported a total of 40 chemical formulations used by the vegetable farmers in Northern Tanzania. This situation is not unique to Tanzania but also true in many other countries where chemical control of crop pests is a dominant strategy [17, 18, 28]. In Benin, Ethiopia, Ghana and Senegal, Williamson et al. [28] recorded 47 different formulations that were used by farmers to control crop pests. Similarly, Ntow et al. [17] reported 43 pesticides that were used by farmers in Ghana to control vegetable pests.

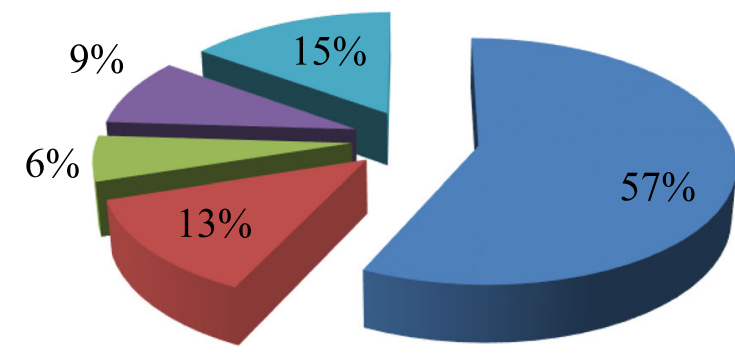

Insecticides

Fungicides

Herbicides

Acaricides

Mixed

Fig. 1 Proportion by class of various pesticides based on the pests they control 
Table 2 Pesticide combinations that were routinely mixed by vegetable farmers in Magu district

\begin{tabular}{lll}
\hline Names of pesticides mixed & Pesticide groups & Chemical group \\
\hline Farm guard + Sume & 1Fungicide + 1Insecticide & Pyrethroid + Organophosphate \\
Shambapowder+ Subachlo + Muparaxone & 2Insecticides + Herbicide & 2 Pyrethroids + Organochlorine \\
Farmzeb + Prefenos + Paraquat & 1Fungicide+ 1 Insecticide+1Hebicide & Carbamate+ Organophosphate+ Organochlorine \\
Linkmil + Fenkil + Mo-Karatap+ Farmguard & 3Insecticides + 1Hebicide & 1Carbamate + 2Pyrethroids \\
\hline
\end{tabular}

The proportion by class of pesticides used in the current study is presented in Table 1 . Contrary to what have been reported from other agro- ecosystem zones where the organophosphates were the dominant group commonly used $[17,29]$ in the present study, pyrethroids were the most used group. This observation is of public health concern because this is the only class of insecticide recommended for use in the insecticide treated nets (ITNs and LLNs) and widely used in indoor residual spray (IRS) vector control programs. The multiple and prolonged exposure of pests to pesticides have been reported to increase selection to resistance [30-32].

The composition of An. gambiae s.l was dominated by An. Arabiensis by $86 \%$ and Anopheles gambiae s.s $8 \%$. The findings are similar to previous studies [33]. It was important to determine species composition because of their ecological and behaviour variations that determines the appropriate methods for their control. These findings are of public health concern because the vector control interventions currently in use (ITNs/LLINs and IRS) target vectors that feed and rest indoors and are less likely to control An. Arabiensis because of its exophilic behavior [34].

Susceptibility test results confirmed high phenotypic resistance among An. gambiae populations against the pyrethroids such as permethrin, cyfluthrin, deltametrin and lambdacyhalothrin, mortality rates 54, 61, 76 and $71 \%$, respectively. The plausible explanation for the observed high phenotypic resistance of An. gambiae s.l against pyrethroids could be the common use of pyrethroids in agriculture (Table 1) and public health (IRS and LLINs). Previous studies conducted in Tanzania [11,35-38] indicated wide-spread resistance to pyrethroid, DDT and bendiocarb among malaria vectors. The loss of natural susceptibility of malaria vectors to insecticides in these studies was attributed to IRS and LLINs interventions following the national universal net distribution campaigns of 2011 and the School Net Program of 2013. Nevertheless, the practice of farmers with regard to pesticide use and handling in relation to vector resistance has not been well established. Many farmers (70\%) used pesticides in mixed form (Table 2) and about $40 \%$ had 3 or more pesticides mixed in the same tank (Table 3). Similar type of pesticide mixing for chemical control of crop pests has been reported from Ecuador [39] and in Indonesia [40]. These pesticides have different modes of action and mechanisms for an intended pest, and thus if not carefully used, resistant mosquito species may develop multiple resistance mechanisms as a result of simultaneous multiple exposures of pesticides due to pesticide cocktails. The practice of pesticide mixing may attest for the failure to detect the knock down resistance $(k d r)$ gene despite high phenotypic resistance levels recorded against population of An. gambiae s.l in the studied area.

The high phenotypic resistance levels observed in this area (Table 4) is attributed to indiscriminate use of pesticides by farmers. In the present study, it was testified by farmers that pesticide cocktails increased the effectiveness of the compound against pests. Farmers also believed that mixing saved time of spray that could have been spent by spraying one pesticide after another. Surprisingly, mosquitoes and other aquatic invertebrates survived such mixtures of pesticide exposures in the surveyed farms in their immature stages. This high tolerance of mosquito larvae to a mixture of pesticides is of public health concern and warrants further research to examine the mechanisms of vector resistance to multiple exposures of pesticides / insecticides. It was also observed during the survey that famers rinsed their sprayers and mixing containers in water bodies found around and within the farms. Other pesticide wastes and remains were directly discharged within these water bodies. These water bodies form mosquitoes' breeding habitats and therefore this practice of discharging the pesticide wastes directly in aquatic habitats may increase the selective pressure of mosquito vectors against the relevant insecticides. The same practice has been observed in Nigeria [18] and among the cotton farmers in Cote d'Ivoire [41]. In Cote d'Ivore (ibid), the practice was associated to fish poisoning, whereas, in other places the contamination of aquatic habitat by pesticides has been considered as the main cause of selection for resistance among disease vectors [42-44]. Similar findings were reported from previous study by Nkya et al. [45]. The buildup of resistance gradually can be an irreversible process that will demand use of increased quantities of pesticides, this will not only increase the pesticide production and expenditure costs but also the potential hazardous effects of pesticides to the environment. Further to note, many farmers $(70 \%)$ used pesticides in mixed form (Table 2) and about $40 \%$ had 3 or more pesticides mixed in the same tank (Table 3). Similar type of pesticide mixing for chemical control of crop pests has been reported from Ecuador [39] and in Indonesia [40]. Pesticides mixing have 
Table 3 Farmer's various pesticide usage practices as reported by respondents during the survey

\begin{tabular}{|c|c|c|}
\hline Variable & Options & $\begin{array}{l}\text { Percentage (\%) } \\
\text { Response }\end{array}$ \\
\hline & Pesticide labels & 17.1 \\
\hline & $\begin{array}{l}\text { Pesticides retailers/ } \\
\text { dealers }\end{array}$ & 45.7 \\
\hline \multirow[t]{6}{*}{$\begin{array}{l}\text { Farmers source } \\
\text { of information }\end{array}$} & $\begin{array}{l}\text { Agricultural extension } \\
\text { officers }\end{array}$ & 5.7 \\
\hline & $\begin{array}{l}\text { Fellow farmers/ } \\
\text { neighbours }\end{array}$ & 25.7 \\
\hline & $\begin{array}{l}\text { News (TV, radio, } \\
\text { magazines) }\end{array}$ & 0 \\
\hline & Others/Unknown & 5.7 \\
\hline & Total & 100 \\
\hline & $1-5$ times per season & 10 \\
\hline \multirow{7}{*}{$\begin{array}{l}\text { Pesticide application } \\
\text { frequency }\end{array}$} & 5-8 times per season & 12.5 \\
\hline & 8-12 times per season & 42.5 \\
\hline & 12-15 times per season & 22.5 \\
\hline & $\begin{array}{l}\text { More than } 15 \text { times per } \\
\text { season }\end{array}$ & 5 \\
\hline & Do not know/remember & 7.5 \\
\hline & Total & 100 \\
\hline & Environmental pollution & 55 \\
\hline \multirow[t]{6}{*}{ Impact of pesticides } & $\begin{array}{l}\text { Killing of non-targeted } \\
\text { species }\end{array}$ & 25 \\
\hline & Pest resistance & 12.5 \\
\hline & Others & 7.5 \\
\hline & Total & 100 \\
\hline & Pesticides singly applied & 20 \\
\hline & Two pesticides mixed & 34.28 \\
\hline \multirow[t]{5}{*}{ Pesticide mixing } & Three pesticides mixed & 28.5 \\
\hline & $\begin{array}{l}\text { Four or more pesticides } \\
\text { mixed }\end{array}$ & 17.14 \\
\hline & Do not know & 0 \\
\hline & Total & 100 \\
\hline & $\begin{array}{l}\text { Poured into rivers, lake/ } \\
\text { bushes }\end{array}$ & 22.8 \\
\hline \multirow[t]{4}{*}{$\begin{array}{l}\text { Fate of pesticide } \\
\text { leftovers }\end{array}$} & $\begin{array}{l}\text { Apply in excess (even } \\
\text { when not required) }\end{array}$ & 34.28 \\
\hline & $\begin{array}{l}\text { Store for the next } \\
\text { application }\end{array}$ & 11.42 \\
\hline & $\begin{array}{l}\text { Dispose on the ground/ } \\
\text { soil }\end{array}$ & 31.42 \\
\hline & Total & 100 \\
\hline \multirow[t]{4}{*}{ Sources of pesticides } & $\begin{array}{l}\text { Provided by the } \\
\text { government }\end{array}$ & 0 \\
\hline & Pesticide retailers shop & 85.7 \\
\hline & Others & 14.3 \\
\hline & Total & 100 \\
\hline
\end{tabular}

been reported to induce resistance selection pressure among crop pests [46].

Spraying was also done unnecessarily even when there was no infestation and majority of farmers (over 60\%) sprayed their farms between 8 and 15 times per cropping season and a few (5\%) reported to have sprayed their farms more than 15 times per cropping season. All these practices were contrary to the instruction labels or the information given by the extension officers. It was further narrated that they applied pesticides many times and in large quantities than the recommended dose because small doses were no longer able to kill the pests. There is, therefore, urgent need to address this rampant and indiscriminate use of pesticides in the present study area, and most probably throughout the country where pesticides are intensively used in a similar manner.

Pesticides were readily available in the study area. The major source of pesticides was the agricultural retailer shops that are located a walking distance from farmers' residencies. It was also observed that pesticide retailers repackaged pesticides into small containers that were cheap and could be afforded even by poorer farmers. The small packs contained no labels about how to use a particular pesticide. In addition, majority of farmers (over $80 \%$ ) reported retailers or fellow farmers (Table 3) as their source of information. It is, therefore, most likely that farmers receive pesticide information from a third part (fellow farmers), which is not reliable. Pesticide labeling was not consistent, some pesticides had no labels at all, and some were completely labeled in English, a foreign language to the majority Tanzanians and therefore farmers could not decipher the technical knowledge in the labels.

Farmers reported the use of pesticides that are not registered for use during the survey. Pesticides of Endosulfan nature Thionex and Thiodan were freely available for sale in open markets and were being used against tomato pests (Table 1). Participants in the present study, further reported the use of expired pesticides from the previous seasons by mixing them with little amount of new pesticides to reduce the costs. It is, therefore, very likely that pesticide induced effect to humans, and environment and other untargeted species such as vector resistance will continue to increase in Tanzania if appropriate measures will not be instituted in time.

\section{Conclusion}

Generally, the intensive use of pesticides is seen to be triggered by occurrence of serious crop pests, the risk of losing crop yields, pesticides' / insecticides' decreased efficacy, farmers desire to increase crop yields and the readily availability of agrochemicals. The high phenotypic resistance levels against Pyrethroids which are not matched with resistance gene imply that vectors have 
Table 4 Mortality rates of An. gambiae s.I. from Magu district $24 \mathrm{~h}$ post-exposure to pyrethroids and DDT, January-September, 2014

\begin{tabular}{|c|c|c|c|c|c|c|c|c|c|}
\hline \multirow[b]{2}{*}{ Insecticide } & \multicolumn{3}{|c|}{ Long rains season } & \multicolumn{3}{|l|}{ Dry season } & \multicolumn{3}{|c|}{ Short rains season } \\
\hline & $\begin{array}{l}\text { No of } \\
\text { mosquitoes } \\
\text { exposed }\end{array}$ & $\begin{array}{l}\text { No of } \\
\text { mosquitoes } \\
\text { survived }\end{array}$ & $\begin{array}{l}\% \text { Mortality } \\
\pm \text { SD }\end{array}$ & $\begin{array}{l}\text { No of } \\
\text { mosquitoes } \\
\text { exposed }\end{array}$ & $\begin{array}{l}\text { No of } \\
\text { mosquitoes } \\
\text { survived }\end{array}$ & $\begin{array}{l}\% \text { Mortality } \\
\pm \text { SD }\end{array}$ & $\begin{array}{l}\text { No of } \\
\text { mosquitoes } \\
\text { exposed }\end{array}$ & $\begin{array}{l}\text { No of } \\
\text { mosquitoes } \\
\text { survived }\end{array}$ & $\begin{array}{l}\% \\
\text { Mortality } \\
\pm \text { SD }\end{array}$ \\
\hline Kisumu & 100 & 0 & $100 \pm 0$ & 100 & 0 & $100 \pm 0$ & 60 & 100 & $100 \pm 0$ \\
\hline Permethrin $0.75 \%$ & 60 & 9 & $85 \pm 0.063$ & 60 & 27 & $54.75 \pm 19.29$ & 60 & 2 & $97 \pm 0.05$ \\
\hline Deltamethrin $0.05 \%$ & 60 & 7 & $88 \pm 0.062$ & 60 & 14 & $76.25 \pm 15.756$ & 60 & 2 & $97 \pm 0.05$ \\
\hline $\begin{array}{l}\text { Lambdacyhalothrin } \\
0.05 \%\end{array}$ & 60 & 0 & $100 \pm 0$ & 60 & 17 & $71.25 \pm 14.773$ & 60 & 0 & $100 \pm 0$ \\
\hline Etofenprox $0.5 \%$ & 60 & 4 & $95 \pm 0.035$ & 60 & 0 & $100 \pm 0$ & 60 & 2 & $100 \pm 0$ \\
\hline Cyfluthrin $0.15 \%$ & 60 & 23 & $61 \pm 0.115$ & 60 & 7 & $88 \pm 11.51$ & 60 & 4 & $97 \pm 0.035$ \\
\hline DDT $4 \%$ & 60 & 3 & $96 \pm 0.04$ & 60 & 0 & $100 \pm 0$ & 60 & 9 & $84 \pm 0.021$ \\
\hline Total & 360 & 46 & & 360 & 65 & & 360 & 19 & \\
\hline
\end{tabular}

SD is standard deviation: Kisumu is the susceptible laboratory strain used for reference

selected for mechanisms other than $k d r$ and this calls for further investigations. Furthermore, the lack of extension services and ineffective environmental and pesticide control policies further explains the indiscriminate use of pesticides. The study recommends regular awareness training to farmers on good farming practices and adoption of integrated pest and vector management that will reduce the use of pesticides, and especially use of pyrethroids to reduce the multiple exposure of pests and disease vectors to pesticides. Furthermore, the Government through the respective authorities should expand the extension services to the village level. The strict enforcement of the existing pesticide and environmental laws is also advocated to reduce the extent of environmental contamination and other risks associated with the use of pesticides. This will reduce the spread of resistance in disease vectors, and this can only be achieved through collaboration of the relevant sectors such as agriculture, livestock and vector control units during the planning of any intervention.

Table 5 Knockdown times (KdT50 and KdT95) in minutes for Anopheles gambiae s.l. populations from Magu agro-ecosystem zone, Mwanza region, January-September, 2014

\begin{tabular}{|c|c|c|c|c|c|}
\hline Season & Insecticide & $\mathrm{KdT}_{50}$ Kisumu & $\mathrm{KdT}_{50}$ An. gambiae s.l. & $\mathrm{KdT}_{95}$ An. gambiae s.l. & $\mathrm{KdT}_{50} \mathrm{R}$ \\
\hline & Permethrin 0.75\% & $44.74[41-46]$ & $38.01[31-43]$ & 63. $37[51-74]$ & 0.85 \\
\hline \multirow[t]{6}{*}{ Long rains } & Deltamethrin 0.05\% & 20.38 [17-22] & $28.31[25-30]$ & $52.67[51-54]$ & 1.39 \\
\hline & Lambdacyhalothrin $0.05 \%$ & 28.56 [28-29] & 26.05 [19-31] & 53.59 [49-60] & 0.91 \\
\hline & Etofenprox $0.5 \%$ & 27.00 [25-28] & $43.47[40-44]$ & $69.51[64-72]$ & 1.61 \\
\hline & Cyfluthrin $0.15 \%$ & 16.23 [12-19] & 41.98 [39-45] & 68.67 [62-77] & 2.58 \\
\hline & DDT $4 \%$ & 35.14 [33-35] & 35.49 [34-35] & $54.49[52-57]$ & 1.01 \\
\hline & Permethrin $0.75 \%$ & $44.74[41-46]$ & $44.40[36-68]$ & $72.61[54-118]$ & 0.99 \\
\hline \multirow[t]{6}{*}{ Dry season } & Deltamethrin $0.05 \%$ & 20.38 [17-22] & $45.36[42-53]$ & $72.31[63-84]$ & 2.23 \\
\hline & Lambdacyhalothrin 0.05\% & 28.56 [28-29] & $44.85[40-50]$ & 70.40 [66-80] & 1.57 \\
\hline & Etofenprox 0.5\% & $27.00[25-28]$ & 34.46 [26-38] & $58.22[52-63]$ & 1.27 \\
\hline & Cyfluthrin $0.15 \%$ & 16.23 [12-19] & $27.91[24-30]$ & 51.01 [49-53] & 1.72 \\
\hline & DDT 4\% & 35.14 [33-35] & 68.11 [45-99] & $114.90[70-180]$ & 1.94 \\
\hline & Permethrin $0.75 \%$ & $44.74[41-46]$ & $62.40[53-69]$ & $103.16[88-114]$ & 1.39 \\
\hline \multirow[t]{5}{*}{ Short rains } & Deltamethrin $0.05 \%$ & 20.38 [17-22] & $40.19[33-42]$ & $64.29[56-68]$ & 1.97 \\
\hline & Lambdacyhalothrin 0.05\% & 28.56 [28-29] & 68.82 [58-82] & 114.97 [95-139] & 2.41 \\
\hline & Etofenprox 0.5\% & 27.00 [25-28] & 48.78 [40-54] & 76.09 [62-86] & 1.81 \\
\hline & Cyfluthrin 0.15\% & 16.23 [12-19] & 50.25 [46-55] & 82.66 [77-92] & 3.09 \\
\hline & DDT 4\% & 35.14 [33-35] & 40.18 [38-14] & 61.47 [58-64] & 1.14 \\
\hline
\end{tabular}




\section{Supplementary information}

Supplementary information accompanies this paper at https://doi.org/10. 1186/s12889-019-7767-0.

\section{Additional file 1. Questionnaire.}

Additional file 2. Susceptibility test results rain season Magu.

Additional file 3. Susceptibility test results dry season Magu.

Additional file 4. Susceptibility test results short rain season Magu.

\section{Abbreviations}

CARTA: Consortium for Advanced Research Training in Africa; DDT: Dichlorodiphenyltrichloroethane; IGP: Intergenic Spacer Region; IRS: Indoor Residual Spray; ITNs: Insecticide Treated Nets; KDR: Knock down resistance; LLINs: Long Lasting Insecticidal Nets; MANOVA: Multiple Analysis of Variance; NIMR: National Institute for Medical Research; NMCP: National Malaria Control Program; PCR: Polymerized Chain Reaction; SNP: Single Nucleotide Polymorphisms; SSA: Sub Saharan Africa

\section{Acknowledgements}

Authors thank CARTA for funding the study through the PhD candidate Anitha Philbert. They are also indebted to the management of the National Institute of Medical Research (NIMR), Mwanza center, Tanzania for supporting the field work and laboratory work at their insectary in Mwanza. Messrs. Epiphany Michael and Michael Sadataeli are thanked for the invaluable support during larvae collection, rearing and bioassays.

\section{Authors' contributions}

AP: Conceived and designed the study, conducted the field and laboratory work, data analysis, interpretation and drafted the manuscript. SLL and GN guided and supervised the study also revised the manuscript. All authors read and approved the final manuscript for submission.

\section{Funding}

This study was funded by the Consortium for Advanced Research Training in Africa (CARTA) through its doctoral fellowship award. Funder had no role in study design, data collection and analysis, decision to publish or preparation of the manuscript. The opinions expressed herein are those of the authors and do not necessarily reflect the views of CARTA.

\section{Availability of data and materials}

All data generated during this study are included in this published article; and its Additional files 2, 3 and 4.

\section{Ethics approval and consent to participate}

The Tanzanian National Institute for Medical Research approved the protocol of this study with approval number NIMR/HQ/R.8a.Vol. IX/2715. The objectives of the study were explained to the respondents and a signed informed consent was obtained from all participants with the help of village leaders. Contact details for the study team were left with respondents in case they needed to follow up with questions/clarifications after the data collection.

\section{Consent for publication}

Not applicable.

\section{Competing interests}

The authors declare that they have no competing interests.

\section{Author details}

'Department of Zoology and Wildlife Conservation, University of Dar es Salaam, Dar es Salaam, Tanzania. ²Department of Molecular Biology and Biotechnology, University of Dar es Salaam, Dar es Salaam, Tanzania.

Received: 30 November 2018 Accepted: 11 October 2019 Published online: 06 November 2019

\section{References}

1. World malaria report 2017. Geneva: World Health Organization; 2017. Licence: CC BY-NC-SA 3.0 IGO
2. Enayati A, Hemingway J. Malaria management: past, present, and future. Annu Rev Entomol. 2010;55:569-91.

3. Hemingway J, Ranson $\mathrm{H}$. Insecticide resistance in insect vectors of human disease. Annu Rev Entomol. 2000:45:371-91.

4. Sharp BL, Ridl FC, Govender D, Kuklinski J, Kleinschmidt I. Malaria vector control by indoor residual insecticide spraying on the tropical island of Bioko, Equatorial Guinea. Malar J. 2007;6:52-7.

5. Rohani A, Zamree I, Lim LH, Rahini H, David L, Kamilan D. Comparative field evaluation of residual-sprayed deltamethrin WG and deltamethrin WP for the control of malaria in Pahang, Malaysia. Asian J Trop Med Public Health. 2006;37(6):1139-48.

6. Giardina F, Kasasa S, Sié A, Utzinger J, Tanner M, Vounatsou P. Effects of vector-control interventions on changes in risk of malaria parasitaemia in sub-Saharan Africa: a spatial and temporal analysis. Lancet Glob Health. 2014;2:601-15.

7. Bauch JA, Gu JJ, Msellem M, Mårtensson A, Ali AS, Gosling R, Baltzell KA. Perception of malaria risk in a setting of reduced malaria transmission: a qualitative study in zanzibar. Malar J. 2013;12:75-84

8. Kaliyaperumal K, Yesuf D. Knowledge, attitudes and practices of local inhabitants about insecticide treated nets (ITNs) for malaria control in an endemic area of Ethiopia. East Afr J Public Health. 2009;6(2):206-2011.

9. Toé PL, Skovmand O, Dabiré RK, Diabaté A, Diallo Y, Guiguemdé TR, Marie J, Doannio C, Akogbeto $M$, Baldet T, et al. Decreased motivation in the use of insecticide-treated nets in a malaria endemic area in Burkina Faso. Malar J. 2009;8:175.

10. Kisinza NW, Nkya ET, Kabula B, Overgaard JH, Massue JD, Mageni Z, Greer G, Kaspar N, Mohamed M, Reithinger R, et al. Multiple insecticide resistance in Anopheles gambiae from Tanzania: a major concern for malaria vector control. Malar J. 2017;16.

11. Matiya DJ, Philbert AB, Kidima W, Matowo JJ. Dynamics and monitoring of insecticide resistance in malaria vectors across mainland Tanzania from 1997 to 2017: a systematic review. Malar J. 2019;18:439-48.

12. WHO. World Malaria Report 2005. WHO, Geneva, Switzerland. In: WHO Geneva: World Health Organization (WHO); 2005.

13. Zaim M, Aitio A, Nakashima N. Safety of pyrethroid-treated mosquito nets. Med Vet Entomol. 2000;14(1):1-5.

14. Jjumba JN, Mosha FW, Lindsay SW. Malaria transmission risk variations derived from different agricultural practices in an irrigated area of northern Tanzania. Med Vet Entomol. 2002;16:28-38.

15. Vanek MJ, Shoo B, Mtasiwa D, Kiama M, Lindsay SW, Fillinger U, Kannady K, Tanner M, Killeen GF. Community-based surveillance of malaria vector larval habitats: a baseline study in urban Dar Es Salaam, Tanzania. BMC Public Health. 2006;6:154-61.

16. Balkew M, Ibrahim M, Koekemoer L, L, Brooke D, B, Engers $H$, Aseffa A, Teshome Gebre-Michael, Elhassen I. Insecticide resistance in Anopheles arabiensis (Diptera: Culicidae) from villages in central,northern and south west Ethiopia and detection of kdr mutation. Parasit Vectors. 2010:3:40-5.

17. Ntow WJ, Gijzen JH, Peter Kelderman P, Drechsel P. Farmer perceptions and pesticide use practices in vegetable production in Ghana. Pest Manag Sci. 2006;62:356-65.

18. Oluwole O, Cheke RA. Health and environmental impacts of pesticide use practices:a case study of farmers in Ekiti state, Nigeria. Int J Agric Sustain. 2009:7(3):153-63.

19. Ngowi AV, Mbise TJ, ljani AS, London L, Ajayi OC. Pesticides use by smallholder farmers in vegetable production in Northern Tanzania. Crop Prot. 2007;26:1617-24.

20. Lekei E, Ngowi VA, London L. Hospital-based surveillance for acute pesticide poisoning caused by neurotoxic and other pesticides in Tanzania. Neuro Toxicology. 2014;9:389-401.

21. Gillies MT, De Meillon B. The Anophelinae of Africa south of the Sahara (Ethiopian zoogeographical region), vol. 54. 2nd ed. Institute for Medical Research: Johannesburg; 1968.

22. Gillies MT, Coetzee M. A Suppliment to the Anophelinae of Africa south of the Sahara (Afrotropical region). Johannesburg: The South African Institute for Medical Research; 1987.

23. WHO. Test procedures for insecticide resistance monitoring in malaria vector mosquitoes. In: WHO. Geneva: World Health Organization (WHO); 2013

24. Scott JA, Brogdon WG, Collins FH. Identification of single specimens of the Anopheles gambiae complex by the polymerase chain reaction. Am J Trop Med Hyg. 1993;49:520-9. 
25. Coetzee M, Craig M, LS D. Distribution of African malaria mosquitoes belonging to the Anopheles gambiae complex. Parasitol Today. 2000; 16:74-7.

26. Martinez-Torres D, Chandre F, Williamson MS, Darriet F, Berge JB, Devonshire AL, Guillet P, Pasteur N, Pauron D. Molecular characterization of pyrethroid knockdown resistance ( $k d r)$ in the major malaria vector Anopheles gambiae s.s. Insect Mol Biol. 1998;7:179-84.

27. Ranson H, Jensen B, Vulule JM, Wang X, Hemingway J, Collins FH. Identification of a point mutation in the voltage-gated sodium channel gene of Kenyan Anopheles gambiae associated with resistance to DDT and pyrethroids. Insect Mol Biol. 2000;9:491-7.

28. Williamson S, Ball A, Pretty J. Trends in pesticide use and drivers for safer pest management in four African countries. Crop Prot. 2008;27: 1327-34.

29. Lekei EE. Establishment of a comprehensive surveillance system for acute pesticicde poisoning in Tanzania. South Africa: University of Capetown; 2012.

30. Hardin MR, Benrey B, Coll M, Lamp WO, Roderick GK, Barbosa P. Athropod pest resurgence: an overview of pontential mechanisms. Crop Prot. 1995;14:3-18.

31. Islam MW, Dastogeer KMG, Hamim I, Prodhan MDH, Ashrafuzzaman M. Detection and quantification of pesticide residues in selected vegetables of Bangladesh. Journal of Phytopathology and Pest Management. 2014;1(2):17-30.

32. Ajayi OC. Biological capital, user costs and the productivity of insecticides in cotton farming Systems in sub-Saharan Africa. Int J Agric Sustain. 2005;3(3):154-66.

33. Philbert A, Lyantagaye SL, Pradel G, Ngwa CJ, Nkwengulila G. Pyrethroids and DDT tolerance of Anopheles gambiae s.l. from Sengerema District, an area of intensive pesticide usage in North-Western Tanzania. Tropical Med Int Health. 2017;22(4):388-98.

34. Mahande A, Mosha F, Mahande J, Kweka E. Feeding and resting behaviour of malaria vector, Anopheles arabiensis with reference to zooprophylaxis. Malar J. 2007;6:100

35. Kabula B, Kisinza W, Tungu P, Ndege C, Batengana B, Kollo D, Malima R, Kafuko J, Mohamed M, Magesa S. Co-occurrence and distribution of east (L1014S) and West (L1014F) African knock-down resistance in Anopheles gambiae sensu lato population of Tanzania. Tropical Med Int Health. 2014;1 11. https://doi.org/10.1111/tmi.12248.

36. Nkya TE, Poupardin R, Laporte F, Akhouayri I, Mosha F, Magesa S, Kisinza W, David JP. Impact of agriculture on the selection of insecticide resistance in the malaria vector Anopheles gambiae: a multigenerational study in controlled conditions. Parasit Vectors. 2014;7:480-91.

37. Kulkarni MA, Rowland M, Alifrangis M, Mosha FW, Matowo J, Malima R. Occurrence of the leucine-to-phenylalanine knockdown resistance (kdr) mutation in Anopheles arabiensis populations in Tanzania, detected by a simplified high-throughput SSOP ELISA method. Malar J. 2006:5:56.

38. Protopopoff N, Matowo J, Malima R, Kavishe R, Kaaya R, Wright A, West PA, Kleinschmidt I, Kisinza W, Mosha FW, et al. High level of resistance in the mosquito Anopheles gambiae to pyrethroid insecticides and reduced susceptibility to bendiocarb in North-Western Tanzania. Malar J. 2013;12:149-56.

39. Crissman CC, Cole DC, Carpio F. Pesticide use and farm worker health in Ecuadorian potato production. Am J Agric Econ. 1994;76:593-7.

40. Indraningsih SY, Widiastuti R. Evaluation of farmers' appreciation in reducing pesticide by organic farming practice. Indones J Agric Sci. 2005:6(2):59-68.

41. Ajayi OC, Akinnifesi FK. Farmers' understanding of pesticide safety labels and field spraying practices: a case study of cotton farmers in northern Côte d'Ivoire. Sci Res Essay. 2007;2(6):204-10.

42. Diabate $A$, Baldet $T$, Chandre F, Akogbeto M, Darriet F, Brengues C, Guiguemde T, Guillet P, Hemingway J, Hougard J. The role of agricultural use of insecticides in resistance to pyrethroids in Anopheles gambiae s.l. in Burkina Faso. Am J Trop Med Hyg. 2002;67:617-22.

43. Overgaard HJ. Malaria mosquito resistance to agricultural insecticides: risk area mapping in Thailand. In: IWMI Research Report Colombo. Sri Lanka: International Water Management Institute; 2006.

44. Georghiou GP. The effect of agrochemicals on vector populations. In: Pesticide resistance in arthropods. New York: Chapman and Hall; 1990a. p. 183-202.

45. Nkya TE, Poupardin R, Laporte F, Akhouayri I, Mosha F, Magesa S, Kisinza W, David JP. Impact of agriculture on the selection of insecticide resistance in the malaria vector Anopheles gambiae: a multigenerational study in controlled conditions. Parasit Vectors. 2014:7:480-91.

46. Metacalf RL. Changing role of insecticides in crop protection. Annu Rev Entomol. 1980:25:119-256.

\section{Publisher's Note}

Springer Nature remains neutral with regard to jurisdictional claims in published maps and institutional affiliations.
Ready to submit your research? Choose BMC and benefit from:

- fast, convenient online submission

- thorough peer review by experienced researchers in your field

- rapid publication on acceptance

- support for research data, including large and complex data types

- gold Open Access which fosters wider collaboration and increased citations

- maximum visibility for your research: over $100 \mathrm{M}$ website views per year

At BMC, research is always in progress.

Learn more biomedcentral.com/submissions 